\title{
Malpraktek dan Hadis Nabi: Menggali Pesan Kemanusian Nabi Muhammad saw. dalam Bidang Medis
}

\author{
Benny Afwadzi ${ }^{1}$ dan Nur Alifah ${ }^{2}$ \\ ${ }^{1}$ Universitas Islam Negeri Maulana Malik Ibrahim Malang \\ ${ }^{2}$ Universitas Islam Negeri Walisongo Semarang \\ afwadzi@pai.uin-malang.com
}

DOI: $10.29240 /$ alquds.v3i1.772

Submitted: 2019-03-11 | Revised: 2019-04-04 | Accepted: 2019-04-16

\begin{abstract}
Malpractice is a humanity phenomenon that has attracted publics attention today. For example, from 2006-2012 there were 182 malpractice cases with various types of negligence. This huge amount is certainly very worrying. Meanwhile on the other hand, the question might arise, did the Prophet Muhammad saw. through hadith ever speak of this phenomenon? If yes, what are the humanity messages contained in these hadiths? This article is written to describe malpractice in the view of hadith. According to the data from hadith collection, both canonic and non-canonic, and combined with interpretatif method, the article concluded that the Prophet Muhammad saw. had discussed the prohibition of malpractice through the hadith narrated by Abu Dāwud and other mukharrij. Indeed, there are at least four messages contained in the hadiths, namely first, the necessity for a Muslim to respect the lives of others, because life is not something cheap in price. Second, in addressing the problem of humanity, even more so in the field of medicine should be done with in a professional manner. Third, the command to always humanize the human while still promoting the spirit of religion (humanitarianism). Fourth, giving a sense of justice to humanitarian system.
\end{abstract}

Keywords: malpractice; prophetic hadith; message of humanity

Abstrak. Malpraktek merupakan fenomena kemanusiaan yang banyak menyita perhatian publik hingga sekarang ini. Tercatat misalnya mulai tahun 2006-2012 terdapat 182 kasus malpraktek dengan berbagai macam kelalaian. Jumlah yang sangat banyak ini tentu sangat mengawatirkan. Sementara itu di sisi lain, mungkin timbul pertanyaan, apakah Nabi Muhammad saw. lewat hadis pernah berbicara mengenai fenomena ini? Jika iya, apa saja pesan-pesan kemanusiaan yang terkandung di dalam hadis-hadis tersebut? Artikel ini hadir untuk menguraikan permasalahan malpraktik dalam pandangan hadis. Dengan data yang berasal dari berbagai kitab hadis, baik kanonik maupun non-kanonik, serta dikombinasikan dengan metode interpretatif, artikel ini menyimpulkan bahwa Nabi Muhammad saw. pada dasarnya telah membicarakan larangan malpraktek lewat hadis yang diriwayatkan oleh Abū Dāwud dan mukharrij yang lain. Lebih lanjut, ada empat pesan yang terkandung di dalamnya, yakni pertama, 
keharusan bagi seorang Muslim untuk menghargai nyawa orang lain, karena kehidupan bukanlah sesuatu yang murah harganya. Kedua, dalam menyikapi problem kemanusiaan, terlebih lagi di bidang kedokteran seharusnya dilakukan dengan cara profesional. Ketiga, perintah untuk selalu memanusiakan manusia dengan tetap mengedepankan semangat agama (humanitarianisme). Keempat, memberikan rasa keadilan pada sistem kemanusiaan.

Kata Kunci: malpraktek; hadis Nabi; pesan kemanusiaan

\section{Pendahuluan}

Islam menetapkan tujuan pokok kehadirannya untuk memelihara agama, jiwa, akal, harta, dan keturunan. Inilah yang dinamakan dengan Maqäshid alSyari'ah (tujuan-tujuan diberlakukannya syariat) ${ }^{1}$. Setidaknya terdapat tiga aspek yang menjadi tujuan hadirnya Islam di muka bumi berkaitan dengan kesehatan, yaitu kesehatan psikis, kesehatan ruhani, dan kesehatan fisik. Hal ini menunjukkan begitu besarnya perhatian Islam terhadap hak hidup manusia. Bahkan, dalam sebuah kondisi tertentu seseorang diperbolehkan mengonsumsi sesuatu yang pada dasarnya haram demi menjaga keberlangsungan hidup dan menghindari ancaman yang membahayakan hidupnya. Fleksibilitas dan elastisitas yang menjadi karakter Islam inilah yang secara eksplisit menunjukkan semangat Islam sebagai agama yang membawa misi memanusiakan manusia.

Dalam bidang kesehatan, kasus malpraktek seringkali terjadi dan cukup menyita perhatian publik. Hal ini karena malpraktek atau kesalahan dalam tindakan medis yang dilakukan oleh dokter sangat melukai pihak korban dan mengguncang jiwa kemanusiaannya. Seyogyanya hal ini tidak perlu terjadi jika seorang dokter benar-benar menyadari bahwa dalam menjalankan profesinya ada hak hidup seseorang yang perlu dijaga dan diselamatkan sesuai dengan kode etik yang ada. Menurut data harian Tempo, tercatat ada 182 kasus kelalaian medis atau malpraktek dalam rentang waktu sejak tahun 2006 sampai 2012, yang terbukti dilakukan dokter di seluruh Indonesia. Dari 182 kasus tersebut, sebanyak 60 kasus dilakukan dokter umum, 49 kasus dilakukan dokter bedah, 33 kasus dilakukan dokter kandungan, dan 16 kasus dilakukan dokter spesialis anak, sedangkan siasanya di bawah 10 macam-macam kasus yang dilaporkan. ${ }^{2}$

Pada dasarnya malpraktek adalah fenomena sosial yang memperoleh perhatian yang signifikan dari banyak pihak, baik kalangan dokter maupun para aktivis hak asasi manusia. Hal ini terjadi karena malpraktek adalah problem di

${ }^{1}$ Abū Ishāq al-Syāthibī, Al-Muwāfaqāt Fì Ushūl Al-Syarīah (Beirut: Dar al-Kutub al'Ilmiyah, 2004).

2 "Sampai Akhir 2012, Terjadi 182 Kasus Malpraktek," Nasional Tempo.Co, accessed February 8, 2019, https://nasional.tempo.co/read/469172/sampai-akhir-2012-terjadi-182kasus-malpraktek. 
dunia medis yang berbalut aspek kemanusiaan, berupa kerugian jiwa dan harta dari pihak korban. Untuk itulah, dalam artikel sederhana ini akan membahas mengenai malpraktek dalam pandangan hadis guna melihat bentuk pesan kemanusiaan dalam bidang kedokteran yang telah disampaikan Nabi. Hadis sebagai salah satu teks agama Islam merupakan realitas yang bersumber dari figur sentral umat Islam, yaitu Nabi Muhammad saw., perlu ditelaah secara komprehensif agar bisa mendapatkan pesan-pesan profetik dari beliau. Makna yang tersimpan di dalamnya harus digali secara optimal sehingga ia benar-benar dapat dijadikan petunjuk (guidance) yang dapat difungsikan sebagai kritik atas aksi-aksi yang mengusik nilai-nilai kemanusiaan yang ada serta menjadi solusi atas berbagai problem yang menerpa kehidupan manusia.

Tulisan ini berusaha menguatkan kajian integrasi antara agama dan ilmu pengetahuan yang seringkali digalakkan di PTKI, terutama pada kajian integratif antara hadis dan ilmu sosial-humaniora. ${ }^{3}$ Jika kajian tentang malpraktik hanya berorientasi pada ranah hukum dan kedokteran sebagaimana banyak penelitian yang ada, maka ia akan cenderung menjadi kajian sekuler. ${ }^{4}$ Padahal disadari atau

${ }^{3}$ Penulis sendiri telah menulis beberapa kajian mengenai integrasi hadis dan ilmu pengetahuan, misalnya Benny Afwadzi, "Membangun Integrasi Ilmu-Ilmu Sosial dan Hadis Nabi," Jurnal Living Hadis 1, no. 1 (December 6, 2016): 101-28, doi:10.14421/livinghadis.2016.1070.; Benny Afwadzi, "Memahami Eksistensi Pendekatan IlmuIlmu Alam Dan Pemahaman Hadis Nabi," in Membangun Kembali Peradaban Islam Prestisius (Malang: UIN Maliki Press, 2016).; Benny Afwadzi, "Integrasi Ilmu-Ilmu Alam dan Ilmu-Ilmu Sosial dengan Pemahaman Hadis Nabi: Telaah atas Konsepsi, Aplikasi, dan Implikasi," Jurnal THEOLOGLA 28, no. 2 (February 20, 2018): 351-90, doi:10.21580/teo.2017.28.2.1972.

${ }^{4}$ Lihat misalnya, Suwari Akhmaddhian, "Analisis Pertanggungjawaban Tenaga Medis Yang Melakukan Tindak Pidana Malpraktek Menurut UU Nomor 36 Tahun 2009 Tentang Kesehatan," UNIFIKASI: Jurnal Ilmu Hukum 1, no. 1 (2014), doi:10.25134/unifikasi.v1i1.33.; Dinarjati Eka Puspitasari, "Aspek Hukum Penanganan Tindakan Malpraktek Medik Di Indonesia," Lambung Mangkurat Law Journal 3, no. 2 (September 30, 2018): 242-61, doi:10.32801/lamlaj.v3i2.86.; Hardisman Hardisman, "Opini Masyarakat Tentang Malpraktek Kedokteran," Majalah Kedokteran Andalas 36, no. 1 (April 30, 2012): 73-86, doi:10.22338/mka.v36.i1.p73-86.2012.; Asep Sukohar and Novita Carolia, "Peran Majelis Kehormatan Etik Kedokteran Indonesia (MKEK) Dalam Pencegahan Dan Penyelesaian Malpraktek Kedokteran," Jurnal Kedokteran Universitas Lampung 1, no. 2 (October 1, 2016): 363 68.; Venny Sulistyani and Zulhasmar Syamsu, "Pertanggungjawaban Perdata Seorang Dokter Dalam Kasus Malpraktek Medis," Lex Jurnalica Journal of Law) 12, no. 2 (2015), https://ejurnal.esaunggul.ac.id/index.php/Lex/article/view/1333.; Priharto Adi, "Formulasi Hukum Penanggulangan Malpraktik Kedokteran," Kanun: Jurnal Ilmu Hukum 15, no. 2 (August 1, 2013): 267-82.; Djoni Djoni, "Hukum Progresif Sebagai Pencegahan Malpraktik Kehutanan Di Indonesia," Jurnal Cakrawala Hukum 5, no. 2 (2014): 123-36, doi:10.26905/idjch.v5i2.694.; Ari Purwadi, "Prinsip Praduga Selalu Bertanggung-gugat dalam Sengketa Medik," Padjadjaran Journal of Law 4, no. 1 (2017): 104-21.; Setyo Trisnadi, "Perlindungan Hukum Profesi Dokter dalam 
tidak, agama berperan besar dalam membentuk perilaku individu atau komunitas tertentu. Memang pada hakikatnya malpraktik adalah persoalan kedokteran sekaligus hukum, tetapi ia perlu juga didialogkan dengan dimensi wahyu, yang dalam hal ini adalah hadis sebagai realitas pergumulan Nabi saw. dengan para sahabatnya. Dengan demikian, kajian terhadapnya akan semakin komprehensif dengan menggabungkan aspek antroposentris dan juga teosentris. Kajian integratif antara malpraktek dengan hadis boleh dikatakan belum mendapatkan perhatiannya di kalangan akademisi. Inilah kontribusi penting yang ingin disuguhkan penulis lewat tulisan sederhana ini.

Kajian dalam tulisan ini berusaha menjawab dua persoalan, yakni apakah Nabi Muhammad saw. sudah membicarakan aktivitas malpraktek di masa lampau ataukah tidak? Jika memang sudah, apa saja pesan-pesan kemanusiaan yang terkandung dalam hadis-hadis tersebut? Dengan menggunakan data hadis yang ada berbagai kitab hadis, baik yang berstatus kanonik maupun nonkanonik, penulis mencoba untuk membuktikan apakah fenomena malpraktek pada dasarnya sudah dibicarakan oleh Nabi saw. di masa lampau atau tidak. Kemudian, untuk menggali pesan-pesan kemanusiaan di dalamnya, digunakan metode interpretatif dengan objek material hadis-hadis tentang malpraktek.

\section{Malpraktek dan Variannya}

Dalam bahasa Indonesia, malpraktek berasal dari kata 'mal' yang berarti buruk dan 'praktik' yang berarti tindakan. Dalam bahasa Inggris, istilah malpraktek diungkapkan dengan malpractice, yang mempunyai makna tindakan yang salah atau cara mengobati pasien yang salah. Sedangkan dalam Kamus Ilmiah Populer, malpraktek diartikan sebagai praktik (kedokteran) yang tidak selaras dengan hukum/peraturan atau praktik/buka praktik (kedokteran) yang menyalahi hukum/peraturan. ${ }^{5}$ Dalam terminologi profesionalisme standar kerja, malpraktek kerap dikaitkan dengan jenis profesi dokter, pengacara, dan akuntan.

Dalam pandangan Azrul Azwar, malpraktek mempunyai tiga arti. Pertama, malpraktek adalah kesalahan profesional yang dibuat oleh dokter, oleh karena pada waktu melakukan pekerjaan profesionalnya, tidak memeriksa, tidak menilai, tidak berbuat atau meninggalkan hal-hal yang diperiksa, dinilai, diperbuat atau dilakukan oleh dokter pada umumnya, di dalam situasi dan kondisi yang sama. Kedua, malpraktek adalah setiap kesalahan yang diperbuat oleh dokter, oleh karena melakukan pekerjaan kedokteran di bawah standar yang sebenarnya secara rata-rata dan masuk akal, dapat dilakukan oleh setiap dokter

Penyelesaian Sengketa Medis," Masalah-Masalah Hukum 45, no. 2 (April 19, 2016): 150-56, doi:10.14710/mmh.45.2.2016.150-156.

5 Pius A. Partanto and M. Dahlan Al Barry, Kamus Ilmiah Populer (Surabaya: Arkola, 1994), 432. 
dalam situasi atau tempat yang sama. Ketiga, malpraktek adalah setiap kesalahan profesional yang diperbuat oleh seorang dokter, yang di dalamnya termasuk kesalahan karena perbuatan-perbuatan yang tidak masuk akal serta kesalahan karena keterampilan ataupun kesetiaan yang kurang dalam menyelenggarakan kewajiban ataupun kepercayaan profesional yang dimilikinya. ${ }^{6}$

Sementara itu, World Medical Association (asosiasi kedokteran dunia) di tahun 1992 menyebutkan malpraktek medis sebagai perilaku dokter berupa kegagalan memenuhi standar dalam penanganan kondisi pasien, atau kekurangterampilan/ketidakompetensian si dokter tersebut, atau karena kelalaian dalam memberikan asuhan kedokteran kepada pasien, yang merupakan penyebab langsung munculnya cedera terhadap pasien. Dalam konteks ini, adanya kelalaian disebabkan seseorang melakukan (commission) atau tidak melakukan (omission) yang seharusnya dilakukan oleh orang lain yang mempunyai kualifikasi yang sama pada suatu keadaan dan situasi yang sama.

Dari beberapa definisi yang dikemukakan oleh para pakar di atas, dapat ditarik kesimpulan bahwa malpraktek atau malpractice merupakan suatu tindakan medis yang buruk -kelalaian medis- yang dilakukan oleh seorang dokter dalam hubungannya dengan pasien, sehingga menyebabkan rasa sakit, luka, cacat, kerusakan tubuh, bahkan kematian, serta bentuk kerugian pasien lainnya. Di Indonesia, fenomena malpraktek seringkali terjadi, sebut saja kasus yang menimpa bayi Wong (salah obat), kasus Siti Aisyah pada tahun 1985 (suntikan oleh bidan), kasus Andriani pada tahun 1986 (operasi mata sampai harus amputasi kaki), kasus Pluit (bedah plastik), ${ }^{8}$ kasus Prita Mulyasari pada tahun 2009 (ketidaksesuaian hasil tes dan diagnosa), ${ }^{9}$ ada pula kasus yang menimpa dr. Dewa Ayu Sasiary dan kedua rekannya yang berawal dari meninggalnya pasien Julia Fransiska Maketey pada tahun 2010 yang mereka tangani, ${ }^{10}$ dan ada juga

${ }^{6}$ Bambang Heryanto, "Malpraktik Dokter Dalam Perspektif Hukum," Jurnal Dinamika Hukum 10, no. 2 (May 15, 2010): 183-91, doi:10.20884/1.jdh.2010.10.2.151.

7 Supriyono Suroso, "Malpraktek Medis," Kompasiana.Com, accessed June 1, 2013, https://www.kompasiana.com/supriyonosuroso/551118f1813311d438bc78ce/malpraktekmedis. Penulis adalah Authorized Mediator for Conflict Resolution (Pusat Mediasi Indonesia Sekolah Pascasarjana UGM).

8 Guwandi, Hukum Medik (Jakarta: FK UI, 2005), 10.

${ }_{9}^{9}$ Putusan No. 300/Pdt.G/2009/PN.Tangerang. RS. Omni Internasional melawan Prita Mulyasari

10 Tempo, "Malpraktek Atau Tidak dr. Ayu? Lihat Empat Poin Ini," (27 November 2013) dalam https://nasional. tempo.co diakses tanggal 8 Februari 2019. 
malpraktek yang dilakukan RS Omni Alam Sutera yang mengakibatkan dua anak kembar menderita cacat mata pada tahun $2018 .{ }^{11}$

Secara umum, malpraktek terbagi menjadi dua macam, yaitu malpraktek etik dan malpraktek yuridik. Malpraktek etik adalah dokter melakukan tindakan yang bertentangan dengan etika kedokteran dalam KODEKI yang merupakan seperangkat standar etis, prinsip, aturan atau norma yang berlaku untuk dokter. Malpraktek jenis ini bisa terjadi pada bidang diagnostik dan terapi. Misalnya saja dalam bidang diagnostik, terdapat pemeriksaan laboratorium yang dilakukan terhadap pasien sebenarnya tidak diperlukan apabila dokter mau memeriksa secara lebih teliti. Akan tetapi, karena laboratorium memberikan janji "reward" kepada dokter yang mengirimkan pasiennya, maka dokter pun tergoda juga mendapatkan hadiah tersebut lalu memberikan rekomendasi pemeriksaan di laboratorium. Contoh lain dalam bidang terapi misalnya ada perusahaan yang menawarkan antibiotika kepada dokter dengan janji kemudahan yang akan diperolehnya bila mau menggunakan obat itu, yang kemudian mempengaruhi pertimbangan dokter dalam memberikan terapi kepada pasien. Orientasi terapi tersebut sesungguhnya tidak sesuai dengan indikasi yang diperlukan pasien, tetapi lebih berdasarkan janji-janji pabrik obat. ${ }^{12}$

Sementara itu, malpraktek yuridik, oleh Soedjatmiko, dibedakan menjadi dua, yakni malpraktek perdata, pidana, dan administratif. Malpraktek perdata (civil malpractice), terjadi apabila terdapat hal-hal yang menyebabkan tidak dipenuhinya isi perjanjian (wanprestasi) di dalam transaksi terapeutik oleh dokter atau tenaga kesehatan lain, atau terjadinya perbuatan melanggar hukum (onrechmatige daad), sehingga menimbulkan kerugian pada pasien. Sedangkan malpraktek pidana (Criminal Malpractice) terjadi apabila pasien meninggal dunia atau mengalami cacat akibat dokter atau tenaga kesehatan lainnya kurang hatihati atau kurang cermat dalam melakukan upaya penyembuhan terhadap pasien yang meninggal dunia atau cacat tersebut. ${ }^{13}$

Malpraktek pidana terbagi menjadi tiga kategori, pertama, malpraktek pidana karena kesengajaan (intensional), misalnya pada kasus-kasus melakukan aborsi tanpa indikasi medis, euthanasia, membocorkan rahasia kedokteran, tidak melakukan pertolongan pada kasus gawat padahal diketahui bahwa tidak ada orang lain yang bisa menolong, serta memberikan surat keterangan dokter yang tidak benar. Kedua, malpraktek pidana karena kecerobohan (recklessness), misalnya

11 "Malpraktik RS Omni Alam Sutera, Daftar Panjang Gugatan Juliana," Metro Tempo.Co, accessed February 8, 2019, https://metro.tempo.co/read/1127875/malpraktik-rs-omni-alamsutera-daftar-panjang-gugatan-juliana.

12 Sudjari Solichin, "Malpraktek Medik," www.elib.fk.uwks.ac.id diakses tanggal 1 Desember 2013.

${ }^{13}$ Ibid. 
melakukan tindakan yang tidak legeartis atau tidak sesuai dengan standar profesi serta melakukan tindakan tanpa disertai persetujuan tindakan medis. Ketiga, malpraktek pidana karena kealpaan (negligence), misalnya terjadi cacat atau kematian pada pasien sebagai akibat tindakan dokter yang kurang hati-hati atau alpa dengan tertinggalnya alat operasi yang di dalam rongga tubuh pasien. ${ }^{14}$

Jenis yang ketiga, yaitu malpraktek administratif (administrative malpractice), terjadi apabila dokter atau tenaga kesehatan lain melakukan pelanggaran terhadap hukum Administrasi Negara yang berlaku, misalnya menjalankan praktek dokter tanpa lisensi atau izinnya, menjalankan praktek dengan izin yang sudah kadaluarsa, dan menjalankan praktek tanpa membuat catatan medik. ${ }^{15}$

Pegangan pokok yang digunakan untuk menetapkan malpraktek cukup jelas, yaitu adanya kesalahan profesional yang dilakukan oleh seorang dokter pada waktu melakukan perawatan dan ada pihak lain yang dirugikan atas tindakan dokter tersebut. Aspek hukum perdata yang menyangkut gugatan seorang pasien terhadap dokter yang menanganinya hampir semuanya adalah masalah tuntutan ganti kerugian. Dalam pasal $1365 \mathrm{KUH}$ Perdata disebutkan bahwa tiap perbuatan melanggar hukum, yang membawa kerugian kepada seorang lain, mewajibkan orang yang karena salahnya menerbitkan kerugian itu untuk mengganti kerugian tersebut. ${ }^{16}$

Jika seseorang pada saat melakukan perbuatan melawan hukum itu mengetahui betul bahwa perbuatannya akan berakibat suatu keadaan tertentu yang merugikan pihak lain, maka pada umumnya seharusnya orang tersebut dapat mempertanggung-jawabkan perbuatannya. ${ }^{17}$ Dalam kaitannya dengan malpraktek, kesalahan bertindak dalam malpraktek terjadi karena kurangnya ketelitian dokter di dalam melakukan observasi terhadap pasien sehingga terjadilah hal yang tidak diinginkan bersama. Ketidaktelitian ini merupakan tindakan yang masuk dalam ketegori tindakan melawan hukum, sehingga menyebabkan kerugian yang harus ditanggung oleh pasien. ${ }^{18}$ Untuk sampai pada kesimpulan ada tidaknya malpraktek sendiri tidaklah mudah, diperlukan banyak

${ }^{14}$ Ibid.

${ }^{15}$ Ibid.

${ }^{16}$ Heryanto, "Malpraktik Dokter Dalam Perspektif Hukum," 186.

${ }^{17}$ Rosa Agustina, Perbuatan Melawan Hukum (Jakarta: Fakultas Hukum UI, 2004), 47. ${ }^{18}$ Alexandra Indriyanti Dewi, Etika Hukum Kesehatan (Yogyakarta: Pustaka Book Publisher, 2008), 267. 
perangkat analisis, seperti dokter lain yang menjadi saksi ahli dan segala macam sarana guna mengungkapkan kebenaran mapraktek itu sendiri. ${ }^{19}$

\section{Analisis Hadis-Hadis Malpraktek}

Dalam dua riwayat Abū Dāwud disebutkan:

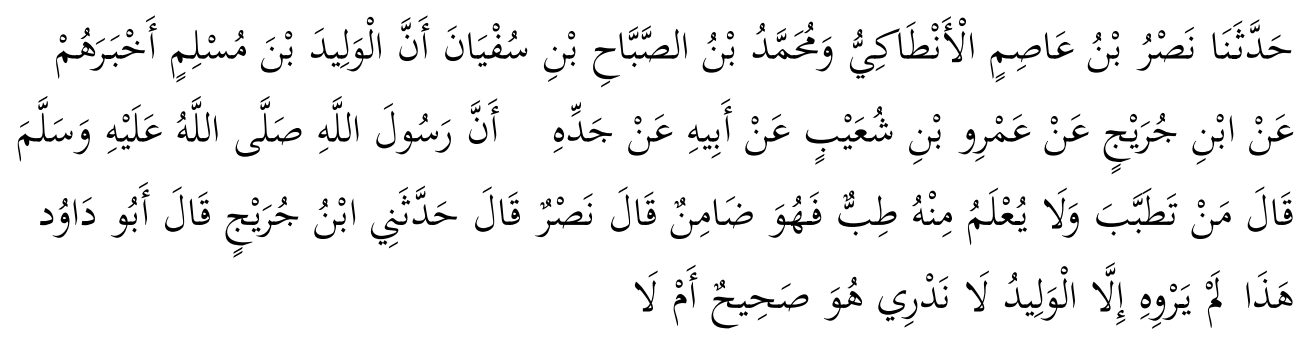

"Berkata pada kami Nashr bin Āsim al-Anthäkī dan Mubammad bin al-Shabbah bin Sufyān, sesunggubnya al-W alìd bin Muslim mengabarkan pada mereka dari Ibnu Juraij dari 'Amr bin Syuaib dari ayahnya dari kakeknya, sesunggubnya Rasulullab saw. bersabda: Barangsiapa yang bertindak sebagai seorang dokter sedangkan ia belum pernab mengkaji ilmu pengobatan sebelumnya, maka ia harus bertanggung jawab atas kerugian yang terjadi (jika ada yang celaka oleh cara pengobatannnya). Nashr berkata, berkata pada saya Ibnu Juraij, Abū Dāwnd berkata, hadis ini tidak diriwayatkan (secara musnad) kecuali dari jalur al-Walid, sedang kami tidak tahu apakah dia sabih (bisa diterima) atau tidak." 20

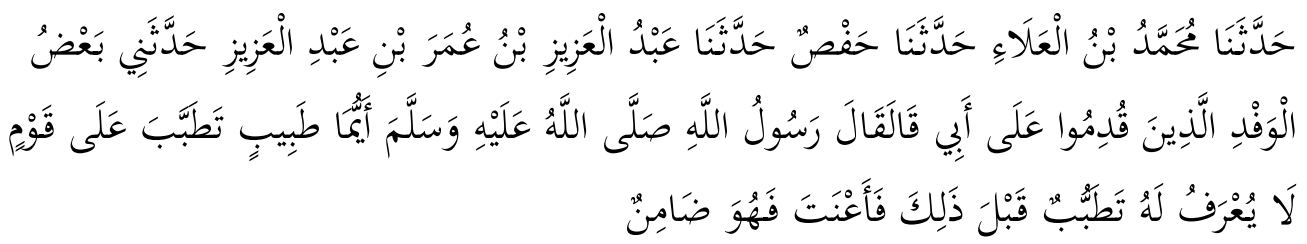

'Berkata pada kami Muhammad bin al-'Alà', berkata pada kami Hafsh, berkata pada kami 'Abd al-'Aziz bin 'Umar bin 'Abd al-'Azì, berkata pada saya sebagian utusan yang didatangkan pada ayah saya, mereka berkata babwa Rasulullah saw. bersabda: Seseorang yang bertindak sebagai seorang dokter lalu merawat orang sakit, sedangkan dirinya tidak mengetahui sebelumnya cara perawatan secara medis yang mengakibatkean penyakit si pasien semakin parah, maka ia harus bertanggung jawab. ${ }^{, 21}$

${ }^{19}$ Muhammad Hatta, "The Position of Expert Witnesses in Medical Malpractice Cases in Indonesia," Al-Abkam 18, no. 1 (October 10, 2018): 47-72, doi:10.21580/ahkam.2018.18.1.2306.

${ }^{20}$ Imam Abu Dawud, Sunan Abu Dawnd (Beirut: Maktab ad-Dirasat wa al-Buhuts fi Dar al-Fikr, n.d.), No. hadis $4586 .$.

${ }^{21}$ Ibid., No. hadis 4587. 
Jika dibaca dari kacamata kritik hadis, dua hadis Abū Dāwud di atas memang tidak lepas dari permasalahan. Hadis pertama tercatat diriwayatkan oleh seseorang bernama al-Walīd bin Muslim yang diperdebatkan. Memang terdapat banyak kitab-kitab kanonik maupun non-kanonik lainnya yang mencantumkan hadis ini, misalnya saja al-Nasā̄î, ${ }^{22}$ Ibnu Mājah, ${ }^{23}$ al-Dār al-Quthnī, ${ }^{24}$ al-Hākim, ${ }^{25}$ dan al-Baihāqī. ${ }^{26}$ Akan tetapi, hadis yang disandarkan pada Nabi secara berurutan melalui rawi-rawi secara sambung (musnad) hanyalah riwayat versi alWalīd, sementara versi selainnya hanya diriwayatkan secara mursal saja. Inilah keganjilan yang ada di dalam hadis ini sebagaimana diungkapkan oleh Abū Dāwud, yang merupakan mukharrij dari hadis ini. Dari hal demikian, Abū Dāwud pun ragu tentang pribadi al-Walīd, apakah ia sahih atau tidak, dengan maksud apakah hadis ini benar-benar bersambung sampai Nabi (musnad) ataukah tidak. ${ }^{27}$

Al-Walīd bin Muslim sendiri dikenal sebagai informan yang suka melakukan tadlis ${ }^{28}$ dan kemungkinan mengambil hadis kalangan pendusta lantas menyembunyikan identitas pendusta tersebut, sebagaimana informasi dari Ibnu Mushir. Namun, menurut Abū al-Thayyib Ābādī, apabila al-Walīd menggunakan redaksi tahammul wa al-adä' berupa haddatsanā (berbicara kepada kami) dalam hadisnya maka perkataannya dapat diambil sebagai hujjah, tetapi jika memakai redaksi 'an (dari) maka hadisnya tidak dapat dipakai sebab ia hanya mendapatkan hadisnya dari pendusta saja. ${ }^{29}$

Meskipun demikian, solusi di atas tampaknya belum menjadi jawaban yang benar-benar solutif, sebab tampak dalam berbagai koleksi kitab, terdapat dua jenis redaksi tahammul wa al-adä' tersebut dalam periwayatan hadis ini. Dalam

${ }^{22}$ Ahmad ibn Syu'aib Abu Abd al-Rahman al-Nasaiy, Sunan Al-Nasa'iy Bi Syarh Al-Hafižb Jalal Al-Din Al-Suyutbiy Wa Hasyiyat Al-Sindiy (Beirut: Dar al-Fikr, 1930), no. hadis 4830.

${ }_{23} \mathrm{Abu}$ 'Abd Allah Muhammad ibn Yazid al-Qazwiniy Ibnu Majah, Sunan Ibnu Majah (Beirut: Dar al-Kutub al-Ilmiyah, 2012), No. hadis 3466.

${ }^{24}$ Alī bin 'Umar al-Dār al-Quthnī, Sunan Al-Dār Al-Quthnì (Beirut: Mu'assasat al-Risālah, 2004), No. hadis 3438, 3439, 4497, 4498, 4499.

${ }^{25}$ Abū 'Abd Allāh Muhammad bin 'Abd Allāh al-Hākim al-Naysābūrī, Al-Mustadrak 'alā Al-Shabihain (Beirut: Dār al-Kutub al-'Ilmiyah, n.d.), No. hadis 7484.

${ }^{26}$ Abū Bakr Ahmad bin al-Husayn bin 'Alī al-Baihaqi, Al-Sunan Al-Kubrā (Hiederabat: Majlis Dāirat al-Ma‘̄āif al-Nizhāmiyat al-Kāinat fì al-Hind bi Baldat Hiederabat, 1344), No. hadis 16971.

${ }^{27}$ Abū al-Thayyib Muhammad Syams al-Haqq al-'Azhīm Ābādī, 'Aun Al-Ma‘būd Syarah Sunan Abi Dūwud (Madinah: Maktabah Salafiyah, 1968), Vol. 9, 1794.

${ }^{28}$ Tadlis adalah akitivitas buruk seorang informan hadis yang menyembunyikan kecacatan hadis dengan tujuan-tujuan tertentu.

${ }^{29}$ Abū al-Thayyib Ābādī, "Al-Ta 'līq Al-Mughnī 'alā Al-Dār Al-Quthnī,” in Sunan Al-Dār Al-Quthnì (Beirut: Mu’assasat al-Risālah, 2004), Vol. 4, 265. 
koleksi Abū Dāwud, al-Baihāqī al-Nasā̄̄ê, dan sebagian al-Dār al-Quthnī memakai 'an, sedangkan dalam koleksi Ibnu Mājah, al-Hākim, dan sebagian alDār al-Quthnī menggunakan baddatsanā. Jika merujuk pada keterangan dalam Sunan Abū Däwud, Nashr bin Āsim memakai haddatsañ dan Muhammad bin alShabbah menggunakan 'an..$^{30}$ Sehingga, tidak dapat dipastikan apa redaksi yang benar-benar diucapkan oleh al-Walīd bin Muslim. Beberapa pakar studi hadis sendiri menerangkan bahwa hadis ini berperingkat sahih atau hasan, misalnya alHākim yang menyebutnya sahih secara isnäd, tetapi tidak ditakhrij oleh alBukhārī dan Muslim. Al-Dzahabi sepakat dengan pendapat al-Hākim tersebut dengan berpendapat bahwa kualitasnya sahih. ${ }^{31}$ Ada pula al-Albānī yang memberikan predikat hasan dengan beberapa pertimbangan tertentu. ${ }^{32}$

Hadis kedua tidak jauh berbeda dengan yang pertama dari sisi permasalahannya. Selain tercantum dalam Abū Dāwud, hadis ini juga diriwayatkan oleh Ibnu Abī Syaibah. ${ }^{33}$ Pada hadis kedua ini, diriwayatkan oleh 'Abd al-'Azīz bin 'Umar dari sebagian utusan (ba'd al-wafd). 'Abd al-'Azīz sendiri merupakan seorang tabi'ut tabi'in, sehingga hadis ini dapat dikategorikan sebagai hadis mursal. Masalah tersebut ditambah dengan informan yang memberitahu kepada 'Abd al-'Azīz yang hanya disebutkan dengan sebagian utusan ( $b a$ 'd alWafd), tanpa disertai nama. Ini berarti informan tersebut berstatus majbul. Dengan demikian, dari logika tersebut, hadis kedua adalah hadis mursal jubälah.

Meskipun diiringi berbagai masalah, tetapi hadis pertama pada dasarnya dapat dianggap telah diperkuat oleh hadis kedua dna begitu pula sebaliknya, sebab keduanya mempunyai makna yang serupa. Dalam termonologi ilmu hadis, sebuah hadis dapat terangkat kualitasnya apabila didukung oleh riwayat lain dengan kualitas yang minimal serupa. Hadis pertama, meskipun dianggap lemah, akan tetapi mendapatkan dukungan makna dari hadis yang kedua. Begitu pula, walaupun hadis kedua lemah, tetapi memperoleh dukungan dari hadis pertama. Dengan demikian, bisa dikatakan bahwa kualitas hadis pertama dan kedua naik dari yang awalnya dhaif (ringan) menjadi hasan lighairibi (karena ada dukungan dari yang lain). Dari logika seperti inilah, al-Albānī menyatakan bahwa kedua hadis dalam problem malpraktek ini berkualitas hasan. ${ }^{34}$

Dengan demikian, berpijak pada dua hadis riwayat Abū Dāwud di atas, apabila dalam masyarakat terjadi tindakan malpraktek yang diakibatkan tidak

30 al-'Azhīm Ābādī, 'Aun Al-Ma'būd Syarah Sunan Abi Dünud, Vol. 9, 1794.

31 al-Naysābūrī, Al-Mustadrak 'alā Al-Shabihain, Vol. 4, 236.

32 Muhammad Nāshir al-Dīn al-Albānī, Al-Silsilab Al-Ahādìts Al-Shahỉhah (Riyadh: Maktabat al-Ma'arif li al-Nasyr wa al-Tauzí', 1995), No. hadis 635, Vol. 2, 226-227.

33 Abū Bakr 'Abd Allāh bin Muhammad bin Abī Syaibah, Musnad Ibn Abì Syaibah (Riyadh: Dār al-Wathan, 1427), No. hadis 984, Vol. 1, 592..

${ }^{34}$ al-Albānī, Al-Silsilah Al-Ahädìts Al-Shabìhah, Vol. 2, 226-227. 
profesionalnya tenaga medis yang bersangkutan, maka orang tersebut harus bertanggung jawab atas kerugian yang diderita pasien, baik harta maupun jiwa. Muatan hadis tersebut pada dasarnya sesuai dengan semangat kenabian yang sangat menghargai nyawa manusia. Nabi Muhammad saw. sebagaimana lazim diketahui, dalam kondisi perang pun sangat menghargai hak hidup manusia. Beliau tidak memperbolehkan pasukannya untuk membunuh anak kecil, wanita, orang yang sudah tua, dan pemuka (pendeta, rahib) agama lain. Ini membutikan bahwa Nabi saw. sebagai panutan umat Islam sangat menghargai nilai-nilai kemanusiaan, bukan sosok yang kejam dan tanpa prikemanusiaan.

\section{Pesan Kemanusiaan dalam Hadis Larangan Malpraktek}

Profesionalisme dalam segala hal memang menjadi tuntutan yang harus dilakukan. Jika seseorang dipandang tidak berkompeten dalam salah satu bidang, maka orang tersebut seyogyanya tidak boleh berbicara apalagi sampai melakukan aksi dalam bidang itu, terlebih lagi dalam bidang kedokteran yang sangat vital kedudukannya, sebab ditakutkan akan mengundang malapetaka bagi pasien di kemudian hari. Dalam sebuah riwayat al-Bukhārī disebukan:

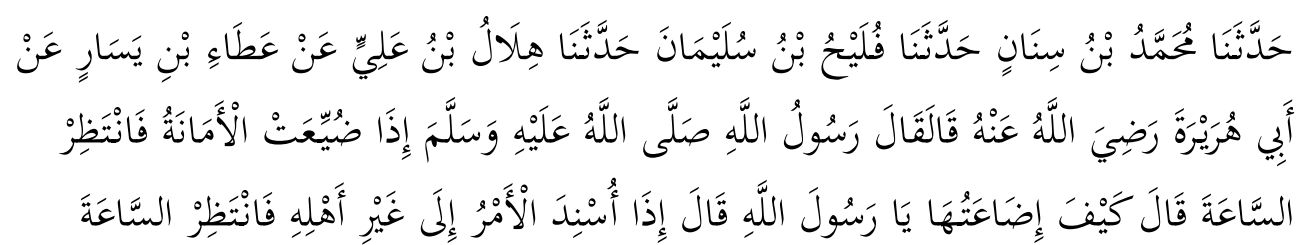

"Berkata pada kami Mubammad bin Sinān, berkata pada kami Fulaih bin Sulaimān, berkata pada kami Hiläl bin 'Alì dari Athä' bin Yasär dari Abü Hurairah yang berkata, Rasulullah saw. bersabda 'apabila suatu amanah disia-siakan, maka tunggulah hari kiamat (kehancuran)-nya'. Seseorang (Arab Badui) bertanya 'Bagaimana menyia-nyiakannya wahai Rasulullah?'. Maka Nabi pun menjawab 'apabila suatu perkara diserabkan pada yang bukan ablinya, maka tunggulah saja kehancurannya (kiamat),35

Salah seorang ulama klasik, al-Kirmānī, memahami makna kata al-amr dalam hadis di atas sebagai sesuatu yang berkaitan dengan bidang agama, misalnya kbiläfah, kepemimpinan (imärah), keputusan hakim, fatwa, dan lain sebagainya. ${ }^{36}$ Pemahaman ini bisa dimengerti sebab asbäb al-wurüd hadis ini adalah adanya seorang Arab Baduwi yang bertanya perihal hari kiamat, sedangkan kiamat sendiri akan terjadi jika persoalan agama seperti disebutkan al-

${ }^{35}$ Abi Abdillah Muhammad bin Ismail Al-Bukhari, Al-Jami' Al-Shabih (Mesir: Maktabah Salafiyah, 1403), No. hadis 6496, Vol. 8, 129.

${ }^{36}$ Syihab al-Din Abu al-Fadhl Ahmad ibn Hajar al-'Asqalani, Fath Al-Bari Bi Syarh Shabih Al-Bukhariy (Beirut: Dar al-Fikr, 1996), Vol. 11, 334. 
Kirmānī diberikan pada yang bukan ahlinya. Namun, interpretasi ini juga bisa diperluas pada konteks lainnya (non-agama) karena pada hakikatnya kata yang dipakai oleh Nabi saw. merupakan redaksi general. Kehancuran (bukan dalam arti kiamat, end the world) akan didapatkan jika semua persoalan diserahkan pada orang yang tidak menguasai persoalan tersebut.

Kedokteran termasuk dari bagian al-amr dalam makna di atas sebagaimana logika yang disampaikan. Dengan demikian, apabila tugas kedokteran diberikan pada orang yang bukan pakarnya atau profesionalitasnya masih diragukan, maka hanya kehancuran saja yang akan didapatkan. Menurut Yamani, pada hakikatnya Islam tidak tidak membenarkan seseorang yang tidak mengkaji ilmu kedokteran turun mengobati pasien. Karena, antara ilmu dan praktik langsung terdapat tanggung jawabnya. Jika terjadi bahaya dalam pengobatan, maka ia harus bertanggung jawab sepenuhnya. ${ }^{37}$

Dalam hadis riwayat Abū Dāwud jelas mengungkapkan bahwa Nabi Muhammad saw. sangat menghargai sisi-sisi kemanusiaan seseorang. Manusia adalah makhluk Tuhan yang paling tinggi derajatnya, sehingga tidak dapat begitu saja diabaikan harkat dan martabatnya. Nabi saw. sebagai pemimpin agama dan negara pada eranya memberikan sebuah instruksi untuk melindungi diri manusia lewat keharusan bertanggungjawab atas segala macam kerugian yang diderita pasien karena ketidakprofesionalan dokter.

Secara lebih luas, pesan-pesan kemanusiaan yang dapat ditangkap dari dua riwayat Abū Dāwud tersebut adalah, pertama, keharusan bagi seorang Muslim untuk menghargai nyawa orang lain, karena kehidupan bukanlah sesuatu yang murah harganya. Yang dimaksud orang lain di sini bukan hanya khusus bagi orang Islam saja, tetapi bagi semua umat manusia, sebab pasien tidak hanya berasal dari kalangan Muslim semata. Dalam kategori maqüshid dharüriah, pesan pertama ini diidentikkan dengan istilah hif ž al-nafs (menjaga jiwa manusia) yang menempati tingkatan pertama atau kedua. ${ }^{38}$

Sementara itu, dalam sebuah ayat, al-Qur'an menyamakan satu kasus pembunuhan orang dengan pembunuhan semua umat manusia; serta menyamakan pemeliharaan sebuah kehidupan dengan pemeliharaan semua

${ }^{37}$ Ja'far Khadim Yamani, Sejarah Kedokteran Islam Dari Masa Ke Masa, trans. Muhammad (Bandung: Prakarsa Insan Mandiri, 1993), 69.

38 Terdapat lima macam maqäshid dharüriah, yang apabila diurutkan dari yang tertinggi sampai terendah adalah al-din (agama), al-nafs (jiwa), al-aql (pikiran), al-nasl (keturunan), dan almāl (harta benda). Sebagian ulama mendahulukan menjaga jiwa daripada agama. Lihat, alSyāthibī, al-Munvāfaqāt, 222, bagian footnote dari muhaqqiq. 
kehidupan yang ada. ${ }^{39}$ Dari ayat tersebut dipahami bahwa kehidupan manusia di muka bumi ini adalah suci (sakral). Manusia adalah satu keluarga, dan setiap kehidupan manusia memiliki nilai yang sama dengan total kehidupan seluruh umat manusia. Pembunuhan dengan cara apapun tidak dibenarkan, sebab ia dipandang sebagai salah satu di antara empat dosa-dosa besar dalam Islam. ${ }^{40}$

Kedua, dalam menyikapi problem kemanusiaan, terlebih lagi dalam bidang kedokteran seharusnya dihadapi dengan cara profesional. Seorang tenaga medis diwajibkan benar-benar mumpuni di bidangnya sebagai bukti penghargaan atas nyawa si pasien. Apabila tidak mampu, maka lebih baik tidak mendekati pasien karena bisa berakibat fatal atau dalam istilah hadis al-Bukhārī yang dipaparkan sebelumnya, akan menemui al-säab (kiamat/kehancuran).

Ketiga, perintah untuk selalu memanusiakan manusia dengan tetap mengedepankan semangat agama (humanitarianisme). ${ }^{41}$ Secara lebih luas, agama berhubungan dengan berbagai persoalan kemanusiaan, dari yang simpel sampai yang kompleks sekalipun, sehingga agama tidak dapat terpisahkan dari persoalan tersebut. Agama diturunkan untuk kepentingan manusia sendiri, bukan Tuhan, dan diperlukan manusia untuk menjalani kehidupan. ${ }^{42}$ Kaitannya dengan ini, hadis Nabi adalah bagian dari agama, sebab dianggap sebagai sumber normatif kedua setelah al-Qur'an. Oleh sebab itu, hadis tidak dapat dipisahkan dari problem-problem kemanusiaan yang ada.

Berpijak pada materi hadis Abū Dāwud, dipahami bahwa dengan adanya konsekuensi tanggungjawab dalam diri seorang dokter, maka secara otomatis Nabi saw. ingin mendudukkan manusia pada tempat yang semestinya. Manusia tidak layak apabila hanya menjadi kelinci percobaan dalam bidang medis, sebab

${ }^{39}$ Secara tekstual, ayat ini memang ditujukan bagi Bani Israil, tetapi maknanya bersifat universal dan dapat diterapkan bagi semua umat manusia sebagai bentuk penghormatan bagi kemanusiaan yang ada. Lihat QS. al-Maidah ayat 32:

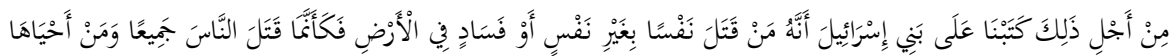

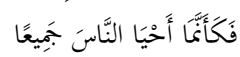

${ }^{40}$ Qader Muheideen, "Bulan Sabit Anti Kekerasan: Delapan Tesis Tentang Aksi-Aksi Kekerasan Umat Islam," in Islam Tanpa Kekerasan, ed. Gleen D. Paige, trans. M. Taufiq Rahman (Yogyakarta: LKiS, 2010), 31.

${ }^{41}$ Terdapat dua istilah dalam usaha memanusiakan manusia, yaitu humanisme dan humanitarianisme. Meskipun keduanya memiliki tujuan yang sama, tetapi mereka mempunyai semangat dan latar belakang yang berbeda. Jika kelahiran humanisme disebabkan oleh keinginan untuk melepaskan diri dari dominasi agama, maka berbeda dengan humanitarianisme yang justru dilatarbelakangi oleh semangat agama. Lihat, Siswanto Masruri, Humanitarianisme Soedjatmoko: Visi Kemanusiaan Kontemporer (Yogyakarta: Pilar Humanika, 2005), 2.

${ }^{42}$ Ibid., 258. 
hal itu tidaklah manusiawi. Jika seseorang menderita penyakit tertentu, sudah sewajarnya ia mendapatkan pertolongan dari orang ahli di bidang itu, bukan dari orang yang hanya mengaku-ngaku sebagai dokter saja.

Keempat, memberikan rasa keadilan pada sistem kemanusiaan yang ada. Tentunya disadari bahwa korban malpraktek pasti merasakan kesengsaraan pasca dibohongi oleh dokter gadungan. Maka dari itu, pertanggungjawaban adalah wujud keadilan hakiki yang wajib dilaksanakan. Lebih konkritnya dapat dikatakan bahwa terma keadilan dalam hadis Abū Dāwud bersifat universal, akan tetapi bentuk pertanggungjawabannya sifatnya partikular, tergantung kebijakan hukum negara masing-masing. Hal ini karena keadilan adalah menilai dan memberi ganjaran atau hukuman menurut perbuatan, sementara wujud hukumannya mengikuti keputusan penguasa setempat. ${ }^{43}$

Pofesionalitas memang menjadi salah satu penyebab terjadinya malpraktek. Namun, sebenarnya malpraktek juga timbul akibat kecerobohan, kurang cermat, atau kealpaan yang ada pada diri seorang dokter dalam melaksanakan tugasnya. Dalam kategorisasi malpraktek, jenis ini termasuk malpraktek yang dapat dituntut secara pidana sebagaimana disebutkan sebelumnya. Berkenaan dengan ini, dalam riwayat Ibnu Mājah disebutkan:
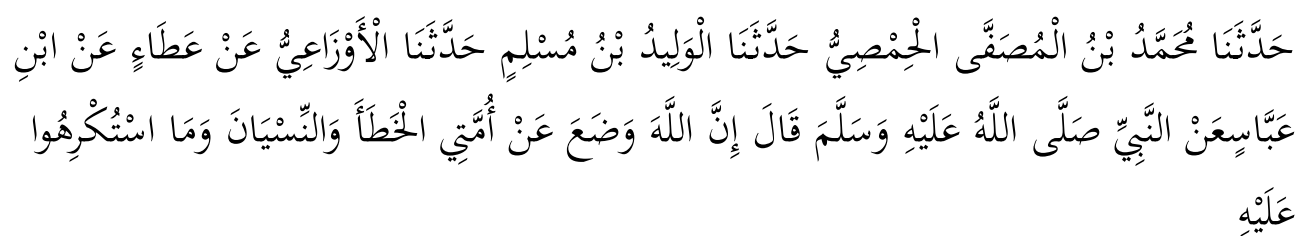

"Berkata pada kami Muhammad bin al-Mushaffā al-Himshì, berkata pada kami al-Walìd

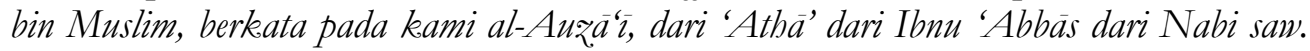
yang berkata: Sesunggubnya Allah meletakkan (pena) dalam salah, lupa, dan sesuatu yang dipaksakan pada umatku,"\$4

Hadis Ibnu 'Abbās di atas seakan kontradiksi dengan fenomena hukuman malpraktek yang berkembang di masyarakat. Jika seorang dokter melakukan kesalahan, yang berakibat fatal, misalnya cacat atau bahkan kematian, maka si pasien atau keluargannya akan siap menuntut dokter yang bersangkutan. Ini termasuk malpraktek pidana, yang tentunya bisa berimplikasi kurungan penjara dan hukuman denda. Realitas ini seakan mengabaikan sisi kemanusiaan dokter yang tidak akan luput dari salah dan lupa. Apabila keterangan dalam hadis tersebut dikolerasikan dengan hukum positif yang berlaku di Indonesia, maka dapat dipahami bahwa kesalahan yang dilakukan dokter profesional tetaplah 1980), 134

43 Marcel A. Boisard, Humanisme Dalam Islam, trans. Rasjidi (Jakarta: Bulan Bintang,

44 Ibnu Majah, Sunan Ibnu Majah, No. hadis 2045, Vol. 1, 659. Ada pula di hadis no. 2043. 
harus dipertanggungjawabkan dalam ranah duniawi (hukum), tetapi tidak menanggung sanksi dari Tuhan (berdosa). Hal ini karena perbuatan yang ada faktor kealpaan atau kesalahan termasuk kategori perbuatan yang dimaafkan sebagaimana hadis di atas.

Malpraktek dengan model seperti ini barangkali bisa diidentikkan dengan pembunuhan karena kesalahan atau yang tidak disengaja (al-qatl al-khata), karena hal tersebut terjadi akibat kesalahan dokter. Dalam studi fikih, pembunuhan jenis ini ada tiga kemungkinan. Pertama, si pelaku melakukan perbuatan dengan tanpa ada maksud melakukan suatu kejahatan, tetapi mengakibatkan kematian seseorang. Kedua, si pelaku sengaja melakukan perbuatan dan mempunyai niat membunuh seseorang yang di dalam persangkaannya boleh dibunuh, tetapi orang tersebut tidak boleh dibunuh, misalnya sengaja menembak seseorang yang disangka musuh dalam peperangan, tetapi ternyata ia adalah kawan sendiri. Ketiga, si pelaku tidak bermaksud melakukan kejahatan, tetapi akibat kelalaiannya dapat menimbulkan kematian, seperti seseorang terjatuh dan menimpa bayi yang berada di bawahnya hingga mati. ${ }^{45}$

Profesionalitas sama-sama dijunjung tinggi oleh hadis dan hukum positif. Dalam riwayat Abū Dāwud dipahami secara implisit bahwa orang yang tidak tahu menahu tentang kedokteran tidak boleh mengobati orang sakit, sementara dalam riwayat al-Bukhārī dinyatakan bahwa jika nekat dilakukan maka akan mengantarkan pada kehancuran (al-sá-ah). Hal ini pun diperhatikan oleh hukum positif, di mana terdapat peraturan Menteri Kesehatan yang menyatakan bahwa seorang dokter yang praktik harus mempunyai Sertifikat Kompetensi, Surat Tanda Registrasi, dan Surat Ijin Praktik. Jika seorang dokter tidak mengantongi tiga surat tersebut, maka pihak yang bersangkutan akan dikenai sanksi pidana, sanksi perdata, dan sanksi administratif. ${ }^{46}$ Surat-surat administratif tersebut sebagai tanda bukti kecakapan seseorang untuk menjalankan kompetensinya sebagai dokter, sehingga terhindar dari kehancuran (al-sä $\left.{ }^{-} a b\right)$ sebagaimana yang disebutkan dalam pesan Nabi saw.

Pada dasarnya, semangat kemanusiaan atau Hak Asasi Manusia (HAM) sangat nampak dalam setiap hukum yang dijabarkan oleh hukum positif di Indonesia. Hal ini pun selaras dengan semangat kemanusiaan dalam dua hadis riwayat Abū Dāwud yang telah dipaparkan sebelumnya. Dalam artian, hukum positif maupun hadis Nabi sama-sama menghargai dan melindungi nyawa seseorang. Pertanggung-jawaban pun menjadi kewajiban yang tidak dapat

\footnotetext{
45 A. Jazuli, Fiqh Jinayah (Jakarta: Raja Grafindo Persada, 1997), 123-24.

${ }^{46}$ Lihat Permenkes RI No. 1419/Menkes/Per/X/2005.
} 
diganggu gugat lagi. ${ }^{47}$ Di samping itu, prinsip-prinsip keadilan bagi semua manusia juga tersimpan rapi dalam kedua landasan hukum itu.

Jika memang semangat kemanusiaan sangat diutamakan dalam hadis Nabi, maka penting bagi setiap Muslim untuk memikirkan kembali hakikat perbuatannya yang tidak sesuai dengan nilai-nilai kemanusiaan. Berdasarkan hadis larangan malpraktek tersebut, jelas secara tersurat maupun tersirat tersimpan larangan untuk menyakiti orang lain, apalagi sampai membunuh. Setiap perbuatan yang dilakukan harusnya berjalan seirama dengan semangat kemanusiaan yang terangkum dalam ajaran agama, yang diwakili oleh hadis maupun hukum positif di Indonesia.

Beberapa persamaan di atas memberikan pemahaman bahwa Islam dan ilmu sosial-humaniora merupakan dua aspek yang saling berkaitan erat dan bukan dua hal yang saling kontradiktif. Hal ini dibuktikan dengan persesuaian semangat kemanusiaan antara hadis sebagai manifestasi Islam dengan hukum positif di Indonesia yang berpijak pada prinsip-prisnsip sosial-humaniora. Sebenarnya persesuaian tersebut bisa dimaklumi, sebab pada hakikatnya agama Islam termasuk social sciense and bumanities, yang memuat ide-ide sosial humaniora dan pengembangannya. Perhatian dan pergumulan epistemologi Islam pun sebenarnya terletak pada wilayah keilmuan sosial-humaniora. ${ }^{48}$

\section{Kesimpulan}

Berdasarkan penjelasan yang sudah diutarakan penulis sebelumnya, dapat diambil konklusi bahwa hadis Nabi saw. lebih kurang dapat menjadi solusi keagamaan bagi problem malpraktek yang menerpa masyarakat. Lebih jauhnya dapat dikatakan bahwa Nabi Muhammad sangat memperhatikan sisi kemanusiaan seseorang. Dalam riwayat Abū Dāwud tentang larangan malpraktek, terkandung makna untuk selalu menghargai nyawa dan hak asasi orang lain. Makna ini secara umum seirama dengan hukum positif di Indonesia, yang menegaskan prinsip serupa. Dengan demikian, sudah sepantasnya aksi-aksi yang menggangu keamanan hak asasi manusia harus segera dimusnahkan karena bertentangan dengan pesan Nabi saw.

Dua hadis koleksi Abū Dāwud menyimpan empat pesan kemanusiaan, yaitu pertama, keharusan bagi seorang Muslim untuk menghargai nyawa orang lain, karena kehidupan bukanlah sesuatu yang murah harganya. Kedua, dalam

\footnotetext{
${ }^{47}$ Mengenai hal ini dalam hukum positif, lihat UU No. 23 tahun 1992 tentang Kesehatan pasal 55 point pertama pada pembahasan sebelumnya yang berbunyi "Setiap orang berhak atas ganti rugi akibat kesalahan atau kelalaian yang dilakukan tenaga kesehatan."

${ }^{48}$ Diistilahkan oleh Amin Abdullah sebagai classical humanities. Lihat M. Amin Abdullah, "AlTa'wil Al-Ilmi: Ke arah Perubahan Paradigma Penafsiran Kitab Suci," Al-Jami'ah: Journal of Islamic Studies 39, no. 2 (2001): 371.
} 
menyikapi problem kemanusiaan, terlebih lagi dalam bidang kedokteran seharusnya dihadapi dengan cara profesional. Ketiga, perintah untuk selalu memanusiakan manusia dengan tetap mengedepankan semangat agama (humanitarianisme). Keempat, memberikan rasa keadilan pada sistem kemanusiaan yang ada.

\section{Bibliografi}

Ābādī, Abū al-Thayyib. "Al-Ta 'līq Al-Mughnī 'alā Al-Dār Al-Quthnī.” In Sunan Al-Dār Al-Quthnì. Beirut: Mu’assasat al-Risālah, 2004.

Ābādī, Abū al-Thayyib Muhammad Syams al-Haqq al-'Azhīm. 'Aun Al-Ma'būd Syarah Sunan Abi Dïnud. Madinah: Maktabah Salafiyah, 1968.

'Abd Allāh bin Muhammad bin Ab̄̄ Syaibah, Abū Bakr. Musnad Ibn Abì Syaibah. Riyadh: Dār al-Wathan, 1427.

Abū Bakr Ahmad bin al-Husayn bin 'Alī al-Baihaqi. Al-Sunan Al-Kubrā. Hiederabat: Majlis Dāirat al-Ma‘ārif al-Nizhāmiyat al-Kāinat fī al-Hind bi Baldat Hiederabat, 1344.

Abu Dawud, Imam. Sunan Abu Dawnd. Beirut: Maktab ad-Dirasat wa al-Buhuts fi Dar al-Fikr, n.d.

Adi, Priharto. "Formulasi Hukum Penanggulangan Malpraktik Kedokteran." Kanun: Jurnal Ilmu Hukum 15, no. 2 (August 1, 2013): 267-82.

Afwadzi, Benny. "Integrasi Ilmu-Ilmu Alam dan Ilmu-Ilmu Sosial dengan Pemahaman Hadis Nabi: Telaah atas Konsepsi, Aplikasi, dan Implikasi." Jurnal THEOLOGIA 28, no. 2 (February 20, 2018): 351-90. doi:10.21580/teo.2017.28.2.1972.

. "Memahami Eksistensi Pendekatan Ilmu-Ilmu Alam Dan Pemahaman Hadis Nabi." In Membangun Kembali Peradaban Islam Prestisius. Malang: UIN Maliki Press, 2016.

. "Membangun Integrasi Ilmu-Ilmu Sosial dan Hadis Nabi." Jurnal Living Hadis 1, no. 1 (December 6, 2016): 101-28. doi:10.14421/livinghadis.2016.1070.

Agustina, Rosa. Perbuatan Melawan Hukum. Jakarta: Fakultas Hukum UI, 2004.

Akhmaddhian, Suwari. "Analisis Pertanggungjawaban Tenaga Medis Yang Melakukan Tindak Pidana Malpraktek Menurut UU Nomor 36 Tahun 2009 Tentang Kesehatan.” UNIFIKASI: Jurnal Ilmu Hukum 1, no. 1 (2014). doi:10.25134/unifikasi.v1i1.33. 
18 | AL QUDS : Jurnal Studi Alquran dan Hadis vol. 3, no 1, 2019

Albānī, Muhammad Nāshir al-Dīn al-. Al-Silsilah Al-Ahādìts Al-Shahīhah. Riyadh: Maktabat al-Ma'arif li al-Nasyr wa al-Tauzī', 1995.

Al-Bukhari, Abi Abdillah Muhammad bin Ismail. Al-Jami' Al-Shahih. Mesir: Maktabah Salafiyah, 1403.

'Asqalani, Syihab al-Din Abu al-Fadhl Ahmad ibn Hajar al-. Fath Al-Bari Bi Syarh Shabih Al-Bukhariy. Beirut: Dar al-Fikr, 1996.

Boisard, Marcel A. Humanisme Dalam Islam. Translated by Rasjidi. Jakarta: Bulan Bintang, 1980.

Dewi, Alexandra Indriyanti. Etika Hukum Kesehatan. Yogyakarta: Pustaka Book Publisher, 2008.

Djoni, Djoni. "Hukum Progresif Sebagai Pencegahan Malpraktik Kehutanan Di Indonesia." Jurnal Cakrawala Hukum 5, no. 2 (2014): 123-36. doi:10.26905/idjch.v5i2.694.

Guwandi. Hukum Medik. Jakarta: FK UI, 2005.

Hardisman, Hardisman. "Opini Masyarakat Tentang Malpraktek Kedokteran." Majalah Kedokteran Andalas 36, no. 1 (April 30, 2012): 73-86. doi:10.22338/mka.v36.i1.p73-86.2012.

Hatta, Muhammad. "The Position of Expert Witnesses in Medical Malpractice Cases in Indonesia." Al-Abkam 18, no. 1 (October 10, 2018): 47-72. doi:10.21580/ahkam.2018.18.1.2306.

Heryanto, Bambang. "Malpraktik Dokter Dalam Perspektif Hukum." Jurnal Dinamika Hukum 10, no. 2 (May 15, 2010): 183-91. doi:10.20884/1.jdh.2010.10.2.151.

Ibnu Majah, Abu 'Abd Allah Muhammad ibn Yazid al-Qazwiniy. Sunan Ibnu Majah. Beirut: Dar al-Kutub al-Ilmiyah, 2012.

Jazuli, A. Fiqh Jinayah. Jakarta: Raja Grafindo Persada, 1997.

"Malpraktik RS Omni Alam Sutera, Daftar Panjang Gugatan Juliana." Metro Tempo.Co. Accessed February 2019. https://metro.tempo.co/read/1127875/malpraktik-rs-omni-alamsutera-daftar-panjang-gugatan-juliana.

Masruri, Siswanto. Humanitarianisme Soedjatmoko: Visi Kemanusiaan Kontemporer. Yogyakarta: Pilar Humanika, 2005.

Muheideen, Qader. "Bulan Sabit Anti Kekerasan: Delapan Tesis Tentang AksiAksi Kekerasan Umat Islam.” In Islam Tanpa Kekerasan, edited by Gleen D. Paige, translated by M. Taufiq Rahman. Yogyakarta: LKiS, 2010. 
Nasaiy, Ahmad ibn Syu'aib Abu Abd al-Rahman al-. Sunan Al-Nasa'iy Bi Syarb Al-Hafizh Jalal Al-Dîn Al-Suyuthiy Wa Hasyiyat Al-Sindiy. Beirut: Dar alFikr, 1930.

Naysābūrī, Abū 'Abd Allāh Muhammad bin 'Abd Allāh al-Hākim al-. AlMustadrake 'alā Al-Shabihain. Beirut: Dār al-Kutub al-'Ilmiyah, n.d.

Partanto, Pius A., and M. Dahlan Al Barry. Kamus Ilmiah Populer. Surabaya: Arkola, 1994.

Purwadi, Ari. "Prinsip Praduga Selalu Bertanggung-gugat dalam Sengketa Medik." Padjadjaran Journal of Law 4, no. 1 (2017): 104-21.

Puspitasari, Dinarjati Eka. "Aspek Hukum Penanganan Tindakan Malpraktek Medik Di Indonesia." Lambung Mangkurat Law Journal 3, no. 2 (September 30, 2018): 242-61. doi:10.32801/lamlaj.v3i2.86.

Quthnī, Alī bin 'Umar al-Dār al-. Sunan Al-Dār Al-Quthnì. Beirut: Mu'assasat alRisālah, 2004.

"Sampai Akhir 2012, Terjadi 182 Kasus Malpraktek." Nasional Tempo.Co. Accessed February 8, 2019. https://nasional.tempo.co/read/469172/sampai-akhir-2012-terjadi-182kasus-malpraktek.

Sukohar, Asep, and Novita Carolia. "Peran Majelis Kehormatan Etik Kedokteran Indonesia (MKEK) Dalam Pencegahan Dan Penyelesaian Malpraktek Kedokteran." Jurnal Kedokteran Universitas Lampung 1, no. 2 (October 1, 2016): 363-68.

Sulistyani, Venny, and Zulhasmar Syamsu. "Pertanggungjawaban Perdata Seorang Dokter Dalam Kasus Malpraktek Medis." Lex Jurnalica (Journal of Law) 12, no. 2 (2015). https://ejurnal.esaunggul.ac.id/index.php/Lex/article/view/1333.

Suroso, Supriyono. "Malpraktek Medis." Kompasiana.Com. Accessed June 1, 2013.

https://www.kompasiana.com/supriyonosuroso/551118f1813311d438b c78ce/malpraktek-medis.

Syāthib̄̄, Abū Ishāq al-. Al-Muwāfaqāt Fì Ushūl Al-Syarīah. Beirut: Dar al-Kutub al-'Ilmiyah, 2004.

Trisnadi, Setyo. "Perlindungan Hukum Profesi Dokter dalam Penyelesaian Sengketa Medis." Masalah-Masalab Hukum 45, no. 2 (April 19, 2016): 150-56. doi:10.14710/mmh.45.2.2016.150-156. 
20 | AL QUDS : Jurnal Studi Alquran dan Hadis vol. 3, no 1, 2019

Yamani, Ja'far Khadim. Sejarah Kedokteran Islam Dari Masa Ke Masa. Translated by Muhammad. Bandung: Prakarsa Insan Mandiri, 1993. 